\title{
Front decompression of sacrum nerve for treatment of congenital spina bifida with meningocele and neural herniation Weiguang Zhang* and Hongxia Zhang
}

\author{
Address: Jinan Bone Orthopedic Hospital, Wuyingshanbei Rd, Jinan, Shandong Province PR China, PC: 250000 \\ Email: Weiguang Zhang* - E32sb@yahoo.com.cn \\ * Corresponding author
}

from 50th Annual Meeting of the Society for Research into Hydrocephalus and Spina Bifida

Cambridge, UK. 30 August - 2 September 2006

Published: 21 December 2006

Cerebrospinal Fluid Research 2006, 3(SuppI I):S44 doi:I0.II86/1743-8454-3-SI-S44

(c) 2006 Zhang and Zhang; licensee BioMed Central Ltd.

\section{Background}

From 1999 to 2004, our hospital treated 4 patients with nerve herniation caused by congenital cystic spina bifida using a new operation method. Case 1, a 5-month girl; case 2, a 3-month-old male infant; case 3, a 10 years old girl and case 4, a 14 years old boy. All 4 patients had fecal and urinary incontinence, all four had talipes calcaneus and impediment of lower limbs; 2 cases have sexual function hypoesthesia; 2 cases have skin ulcer; 1 case has chronic osteomyelitis; 1 case has complicated uraemia; 1 case had a bladder fistulization of abdominal wall and 1 case has hydrocephalus.

\section{Materials and methods}

1) Patients lie on one side;

2) Epidural anesthesia or general anesthesia;

3) A longitudinal incision of about $8 \mathrm{~cm}$ is made along the sacrum and lower lumbar;

4) Cut the tissue under the dural cyst to expose the dural cyst and vertebrae

5) Dissect the sacral nerve and lumbar nerve, loosen the conglutination and release the pressure;

6) Cut open the dural cyst and drain some cerebrospinal fluid;
7) Release the tethered sacrum nerve and sacrum vertebrae, move up the dural cyst, and surrounding nerves about 3-5 cm;

8) Repair the meninges containing no nerves, put back the meningeal cyst and cover under the hypodermis.

9) Clean the incision with physiological saline and place a drainage tube;

10) Incision is closed with interrupted suture

\section{Results}

Assessment aspects: 1). meningocele and neural herniation; 2). Bladder function; 3). Bowel function, 4). Sexual function; 5). Function of lower limbs and talipes calcaneus; 6). Hydrocephalus; 7). Skin ulcer; Assessment criteria: 1) Excellent: all aspects restored; 2) Good: 4-6 aspects restored; 3 ) Fair: 1-3 aspects restored; 4) Poor: no respect restored and 5) Failure: 1-7 aspects become worse.

Assessment result: Excellent 4 cases, Good 0 cases, Fair 0 cases, Poor 0 cases and Failure 0 cases. One case with osteomyelitis complication is cured by combination of Chinese traditional and Western medicine; one case with uraemia complication is cured;

\section{Conclusion}

It is difficult to treat complicated meningocele and nerve herniation caused by congenital spina bifida. We have 
treated 4 patients using the new operation method. According to the knowledge and treatment condition of this disease, we think the cure rate for patients with meningocele and nerve herniation is higher than that for patients with meningocele only.

Publish with Bio Med Central and every scientist can read your work free of charge

"BioMed Central will be the most significant development for disseminating the results of biomedical research in our lifetime. " Sir Paul Nurse, Cancer Research UK

Your research papers will be:

- available free of charge to the entire biomedical community

- peer reviewed and published immediately upon acceptance

- cited in PubMed and archived on PubMed Central

- yours - you keep the copyright

Submit your manuscript here:

http://www.biomedcentral.com/info/publishing_adv.asp 